\title{
Assessment of the innovative potential of agriculture of the member states of the Eurasian Economic Union
}

\author{
Dmitry Morkovkin ${ }^{1}$, Iryna Hutarava $^{2}$, Elizaveta Ogloblina ${ }^{1}$, Arthur Gibadullin ${ }^{3, *}$, and \\ Svetlana Kharchenko ${ }^{1}$ \\ ${ }^{1}$ Financial University under the Government of the Russian Federation, 49, Leningradsky avenue, \\ Moscow, 125993, Russian Federation \\ ${ }^{2}$ Belarusian State University, 4, Nezavisimosti Avenue, Minsk, 220030, Belarus \\ ${ }^{3}$ State University of Management, 99, Ryazan Avenue, Moscow, 109542, Russian Federation
}

\begin{abstract}
The study is devoted to assessing the innovative potential of agriculture of the member states of the Eurasian Economic Union. As part of the work, it was revealed that the Member States of the Union were united in order to ensure sustainable development in the current and strategic perspective. The analyzed agricultural indicators led to the conclusion that the Russian Federation is the absolute leader in terms of gross output and distribution of agricultural products, the Republic of Kazakhstan occupies the second place, and the Republic of Belarus in third place. At the same time, the specific indicator reflecting the collection and production of agricultural products per capita, which indicates the innovative development of agriculture, was analyzed in the work, as a result, it was revealed that the Russian Federation ranks last in terms of certain indicators. In this connection, mechanisms were proposed in the work aimed at increasing the innovative development of agriculture in the member states of the Eurasian Economic Union.
\end{abstract}

\section{Introduction}

The creation of new integration blocks is associated with the unification of states under common ideas and the formation of common areas of development, including industrial and innovative, ensuring the exchange of goods and services, the flow of capital and labor, as well as the creation of common markets for food, fuel and energy resources, medicines etc [1]. Of course, in the context of the integration of national states, issues of ensuring food security of the states that are members of this association are becoming more acute. Historically, these associations, which are part of the Eurasian Economic Union (EAEU), existed and developed together and had common requirements for building a governance structure, developing activities, planning, etc., which is an advantage for such integration units [2-4].

\footnotetext{
*Corresponding author: 11117899@mail.ru
} 
The Eurasian Economic Union began to form at the end of the 20th century with the goal of creating common relations between states to maintain a balance of production and consumption of goods and services, mutual assistance, achieve global supranational goals, formulate and implement joint strategic initiatives and other tasks. To date, the following states are included in the Eurasian Economic Union - the Republic of Armenia, the Republic of Belarus, the Republic of Kazakhstan, the Republic of Kyrgyzstan and the Russian Federation. Modern conditions for the development of a supranational bloc require the convergence of all areas of activity, and the formation of general rules for the development of the Union [5].

Many studies have been devoted to assessing the innovative potential of the member states of the Eurasian Economic Union, which reflect the leading advantage of the Russian Federation over other countries. However, we consider it necessary to analyze the innovative potential of agriculture of the Eurasian Economic Union, since agriculture is the system industry in the Republic of Belarus and the Republic of Kazakhstan.

\section{Materials and methods}

The purpose of the presented study is to assess the innovative development of agriculture of the Eurasian Economic Union. The following tasks were set in the study:

- To analyze the agricultural potential of the Member States of the Union, including innovative development;

To propose a system for ensuring the innovative development of agriculture of the Eurasian Economic Union.

The presented study is based on the analysis of statistical data published in open sources, and the scientific methods and approaches used in the study allowed to reveal the goal of the work.

\section{Results}

The studies devoted to the analysis of the Eurasian Economic Union mainly examine the gross indicators of development of individual states and their advantages over other EAEU member countries. If we consider the gross indicators, it can be noted that in almost all areas of activity the leader is the Russian Federation, the second place, as a rule, is occupied by the Republic of Kazakhstan, and the third, mainly the Republic of Belarus. A similar situation arose due to the territorial scale of some states over others, the number of residents, the presence of potential in various fields of activity, international relations with other countries of the world, and other advantages that countries formed as a result of independent existence and development [6-7].

It is advisable to start assessing the innovative potential of agriculture of the Eurasian Economic Union by analyzing the entire agricultural complex of the Union. It is advisable to consider any field of activity in such integration blocks by gross and specific indicators, of course, gross indicators will depend on the scale of states, their development, the availability of necessary means and objects of labour, which allow developing various fields of activity and ensuring the formation of added value in the economy. Specific indicators reflect the volume of production per capita, which indicates the effectiveness of agriculture and overall innovative development [8].

In our opinion, since agriculture is a strategic and life-supporting industry, it is advisable to consider both gross and specific indicators, the latter of which will reflect the level of innovative development of agriculture in the EAEU member states. Consider the distribution of agricultural production by EAEU member states (figure 1) [9]. 


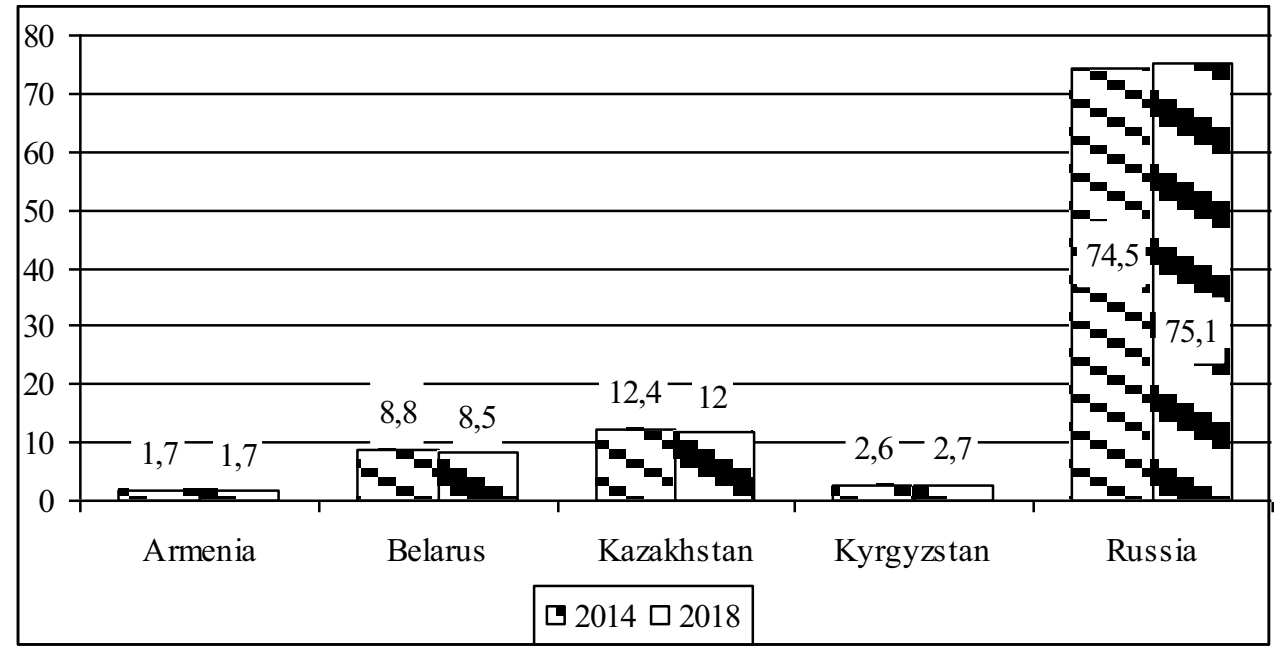

Fig 1. Distribution of agricultural output by EAEU member states, in percent.

It can be seen from the figure that for five years the volume of production has not changed, while Russia is the leader, the next is the Republic of Kazakhstan, and the Republic of Belarus is in third place.

Further, it is advisable to consider the volume of agricultural production in monetary terms (figure 2) [9].

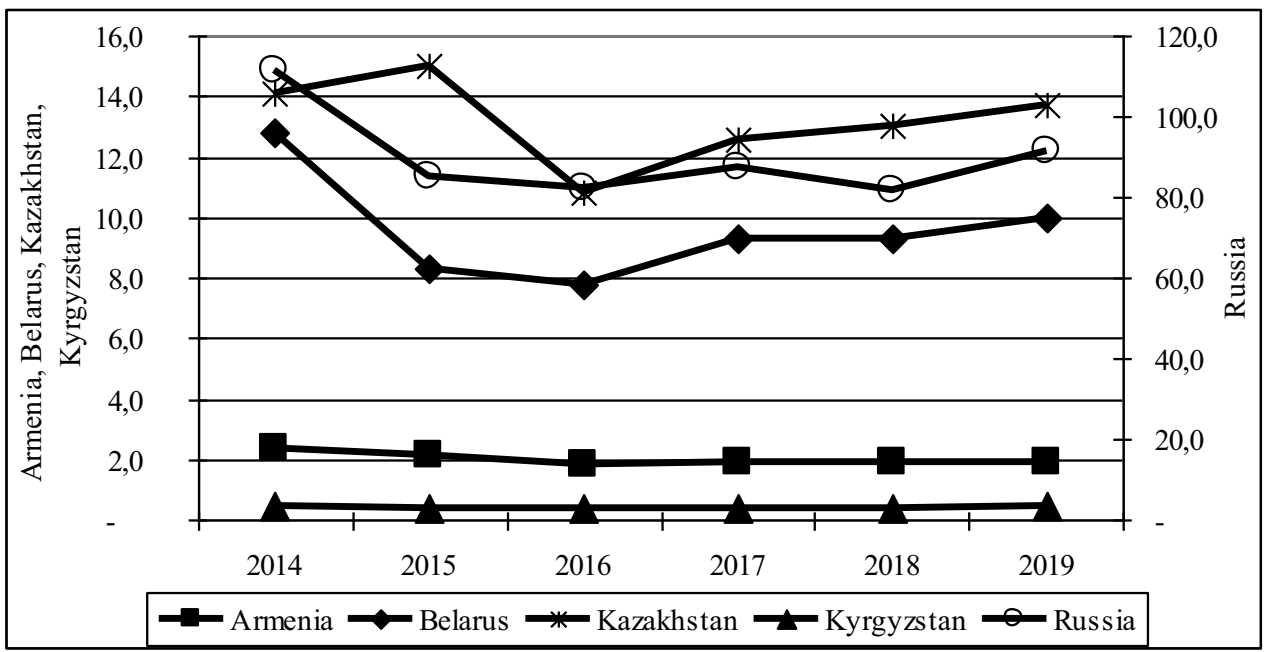

Fig. 2. The volume of agricultural production, billion US dollars

The figure shows that Russia is a leader in terms of agricultural production in cash terms, while the Republic of Belarus and the Republic of Kazakhstan annually receive more than $\$ 10$ billion from agricultural production.

Thus, it is clear that the distribution of production and the volume of production in the EAEU member states is uneven, however, it seems interesting to analyze the innovative activity of the agricultural complex of these states [10-11].

Innovative development or innovation in the modern scientific literature is considered from different points of view, for example, individual scientists consider innovation 
exclusively as the creation of new technological devices that increase production efficiency, ensure the production of modified and new products, reduce the consumption of resources, etc. However, other authors believe that it is advisable to include technological, product, organizational, marketing, environmental and other types of innovations in innovative development, that is, a set of measures in various fields of activity that allows to increase the innovative level of the final product or the entire production. In our study, when analyzing agriculture, we will adhere to the last position, which includes a set of various measures in innovation [12].

In our opinion, it is possible to consider a consolidated indicator of innovation activity in various countries through a specific indicator reflecting the collection and production of agricultural products (figure 3) [9].

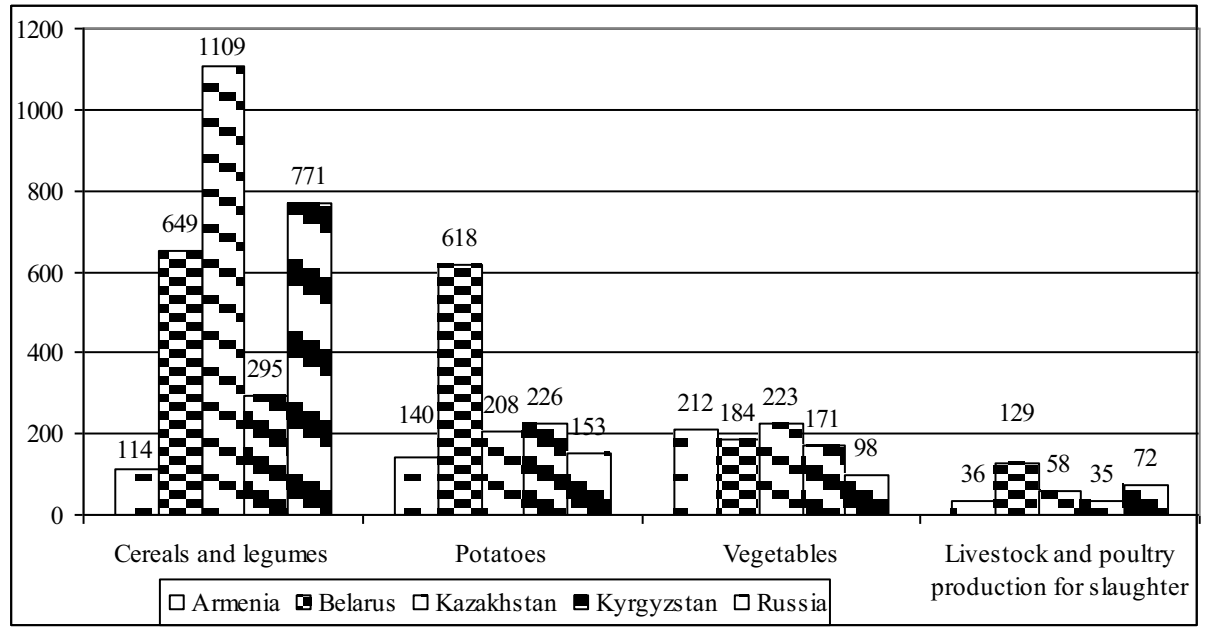

Fig. 3. The collection and production of agricultural products in 2018 , kilogram per capita

From the presented figure it can be seen that the specific indicator reflecting the collection and production of agricultural products in different countries differs for all considered indicators and, within the framework of the presented indicators, it is impossible to determine the leader. However, it is worth noting that the Republic of Kazakhstan and the Republic of Belarus are practically ahead of the Russian Federation in all respects. At the same time, the specific indicator of the collection of vegetables in Russia is in last place, and for the collection of potatoes it is comparable with the Republic of Armenia. Thus, we can conclude that Russia is not an absolute leader in the specific indicator reflecting the collection and production of agricultural products, that is, it can obviously be said that organizational, product, technological, process and other types of innovations are ineffectively applied in Russia.

At the same time, in recent years, the development of organic agriculture, which according to the Codex Alimentarius should act as an "integrated production management system that promotes and improves the health of the agro ecosystem, including biological diversity, biological cycles and biological activity of the soil," has become a topical trend in agriculture [13].

In light of the foregoing, the development of organic agriculture and organic production for the member states of the Eurasian Economic Union is becoming a priority in terms of providing the population with quality food, developing agribusiness, and strengthening the innovative and export potential of these countries. 
Considering the specifics of the development of organic agriculture in the EAEU member states, three main areas can be distinguished:

- The creation of a regulatory framework for the development of organic agriculture and the production of organic products.

The Republic of Armenia is the first country among the EAEU member states where the Law on Organic Agriculture was adopted in 2009. Then, in 2015, the legal framework for the development of organic agriculture and organic production was created in the Republic of Kazakhstan. In 2019, the Law on Organic Agricultural Production in the Kyrgyz Republic was adopted in the Republic of Kyrgyzstan, and the Law on Organic Production and Circulation came into force in the Republic of Belarus. In turn, in the Russian Federation, the Federal Law "On Organic Products and Amending Certain Legislative Acts of the Russian Federation" entered into force in early 2020. It is necessary to pay attention to the fact that it is advisable that the regulatory and regulatory framework created among the EAEU member states the legal framework in the field of organic agriculture was in line with the Codex Alimentarius rules.

- The study of a certain experience and vector in the development of organic agriculture of the EAEU member states.

In the Republic of Armenia in the modern world, a course has been taken towards the development of green agriculture, which will create a certain added value, increase the competitiveness of agricultural products, and contribute to the development of innovative agriculture. Since 2020, the "EU Green Agriculture Initiative of Armenia" program has been operating in Armenia.

The Republic of Kazakhstan has defined a vector for the modernization of agriculture with an emphasis on the development of organic agriculture. This direction is defined in the "Kazakhstan-2050 Strategy", "New Political Course" and "Third Modernization of Kazakhstan: Global Competitiveness". The main crops of organic agriculture are oilseeds, grains, legumes and medicinal plants.

The Republic of Kyrgyzstan positions itself as a state of environmentally friendly products. Over 6000 tons of organic products were grown in 2019 in 23 villages, 898 farmers were trained in organic farming, 7860 hectares of organic land were removed by sequential soil cleaning. The main crops of organic agriculture are cotton, potatoes, tobacco, carrots, table beets, cabbage, garlic, apricot, pears, apples, berries, medical and flavoring plants, fodder herbs.

In the Republic of Belarus, in the "National Strategy for the Sustainable Social and Economic Development of the Republic of Belarus until 2030", one of the criteria for the development of agriculture is the growth of the share of organic land in the total area of agricultural land to 3-4 percent by 2030. In 2017, there were 11 producers of organic production, 6 large exporters of mushrooms, wild berries and birch sap, 2742 hectares of certified land for harvesting wild plants. In 2019, 25 organic production facilities were operating. The main crops of organic agriculture are vegetables and berries, cereals and oilseeds.

In the Russian Federation, the Doctrine of Food Security is also being implemented through the development of organic agriculture. In 2017, in the Russian Federation, the total area certified for organic farming amounted to 385 thousand ha., About 60 organic production facilities were functioning. The Russian Federation is a country with great potential for the development of organic agriculture. The main crops of organic agriculture are cereals and legumes, pine nuts, fruits and vegetables, organic wild plants.

The international turnover of organic agricultural products in the Union in 2017 amounted to $\$ 90$ billion and, according to expert estimates; by 2020 the international turnover of organic products in the EAEU member states will increase to $\$ 130$ billion. 
- Agitation of information on the development of organic agriculture of the member states of the Eurasian Economic Union. This direction is relevant for all EAEU member states.

In light of the foregoing, for the member states of the Eurasian Economic Union, the development of organic agriculture is an urgent priority. At the same time, the development of organic production in the Union is one of the strategic tasks [14-16].

Thus, due to the fact that there is certain heterogeneity in the development of agriculture in the EAEU member states, and the considered certain indicators in certain areas of activity differ significantly; we consider it necessary to propose a system for ensuring the innovative development of agriculture of the Eurasian Economic Union.

\section{Discussions}

The development of agricultural innovation activity of the Eurasian Economic Union should be considered in the prism of all states, therefore it is advisable to propose mechanisms and develop measures that will provide a synergistic effect from the interaction of states to achieve a common goal. Moreover, the analysis showed that Russia is not a leader in the innovative development of agriculture, and therefore, the experience of countries such as Belarus and Kazakhstan should be expanded to other countries of the Union.

We consider it necessary to propose a system that allows for the innovative development of agriculture of the Eurasian Economic Union (figure 4) [17-19].

EAEU Agricultural Innovation Development Systems

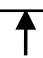

Formation of an innovative and digital platform that will ensure the collection, accumulation, analysis, evaluation and transformation of the received information flows on the state and experience of agricultural development of the EAEU member states

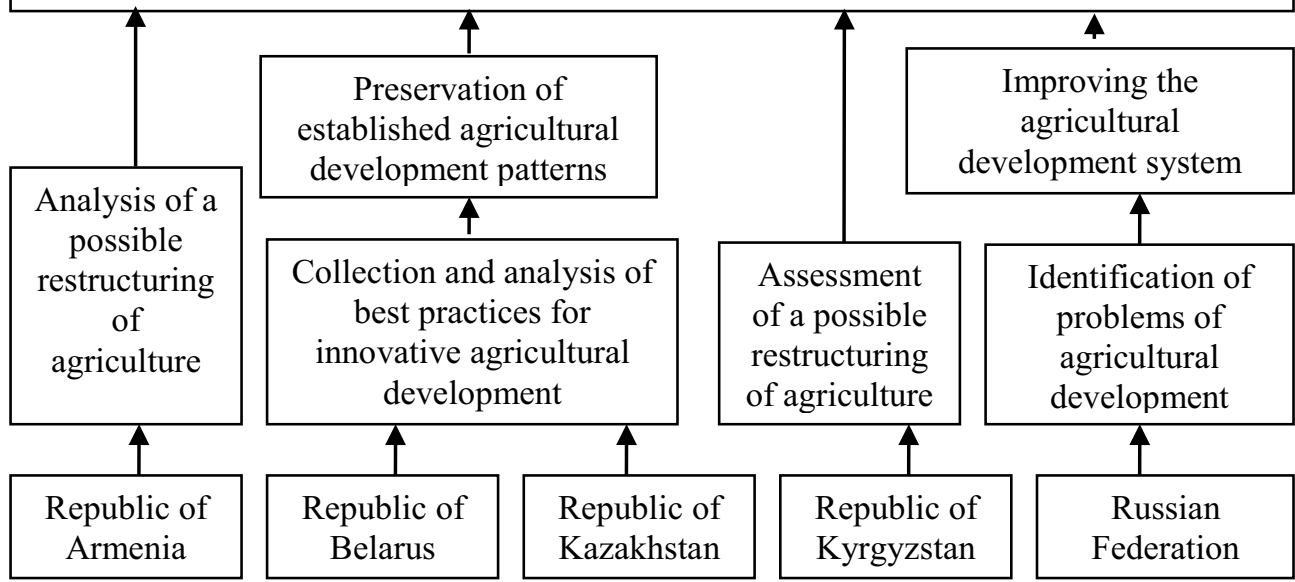

Fig. 4. The system for ensuring the innovative development of agriculture of the Eurasian Economic Union.

Thus, the presented system shows that it is possible to ensure the innovative development of agriculture in the EAEU member states due to the incomplete restructuring of agriculture in all countries, and the adjustment of lagging states to best practices. Of course, such an approach will reduce operating and capital costs and ensure a gradual 
sustainable growth of the EAEU agriculture. It is advisable to transform the proposed approaches into all types of activities whose convergence is planned within the framework of the Eurasian Economic Union.

\section{Conclusion}

The presented study was devoted to assessing the innovative potential of agriculture of the Eurasian Economic Union. The study analyzed indicators reflecting the development of the EAEU agriculture, which showed that Russia is the leader in terms of gross indicators. The study evaluated specific indicators reflecting the volume of output per capita, within the framework of which it was revealed that the Russian Federation is not a leader, and the Republic of Belarus and the Republic of Kazakhstan occupy the first places. The work proposed a system for ensuring the innovative development of agriculture of the Eurasian Economic Union, which requires lagging states to adapt to the best practices of innovative agricultural development of the Republic of Belarus and the Republic of Kazakhstan.

\section{References}

1. A. Gibadullin, V. Pulyaeva, T. Usmanova, I. Ivanova, L. Vlasenko, E3S Web of Conferences, 164, 11017 (2020)

2. I.N. Romanova, D.E. Morkovkin, V.N. Nezamaikin, A.A. Gibadullin, M.A. Ivanova, IOP Conference Series Materials Science and Engineering, 734, 012166 (2020) DOI: 10.1088/1757-899X/734/1/012166

3. V.I. Tinyakova, V.V. Davnis, E.V. Miroshnikov, M.A. Chervontseva, I.Y. Proskurina, International Journal of Engineering and Advanced Technology, 8, 6, 2, 1107-1111 (2019) DOI: 10.35940/ijeat.F1327.0886S219

4. A. Gibadullin, V. Abramov, T. Usmanova, S. Bryukhovetskaya, A. Borisov, O. Afanasieva, E3S Web of Conferences, 164, 11018 (2020)

5. A. Gibadullin, V. Pulyaeva, E3S Web of Conferences, 114, 02002 (2019) https://doi.org/10.1051/e3sconf/201911402002

6. S.V. Bryukhovetskaya, K.A. Artamonova, A.A. Gibadullin, S.A. Ilminskaya, Z.M. Kurbonova, IOP Conference Series: Earth and Environmental Science, 421, 042018 (2020) DOI: 10.1088/1755-1315/421/3/042018

7. Z.K. Omarova, S. Ivanovichnikishov, A.S. Ellaryan, A.D. Bobryshev, E.Y. Kamchatova, Journal of Advanced Research in Dynamical and Control Systems, 10, S10, 581-586 (2019) DOI: 10.5373/JARDCS/V11SP10/20192845

8. D.E. Morkovkin, Ch.V. Kerimova, O.I. Dontsova, A.A. Gibadullin, Journal of Physics: Conference Series, 1399, 033042 (2019) DOI:10.1088/1742-6596/1399/3/033042

9. Russian statistical yearbook 2019 (Moscow: Rosstat) 708

10. D. Morkovkin, D. Lopatkin, M. Sadriddinov, T. Shushunova, A. Gibadullin, O Golikova, E3S Web of Conferences, 157, 04015 (2020) DOI: https://doi.org/10.1051/e3sconf/202015704015

11. Yu. D.Vishnyakov, S.P. Kiseleva, L.V. Makolova, V.V. Pham, T.T. Vu Huong, Upravlenie, 7, 2, 24-31 (2019) DOI: 10.26425/2309-3633-2019-2-24-32

12. S.A. Tolkachev, A.A. Bykov, D.E. Morkovkin, O.I. Borisov, A.V. Gavrilin, IOP Conference Series: Earth and Environmental Science, 421, 032041 (2020) DOI: $10.1088 / 1755-1315 / 421 / 3 / 032041$ 
13. I.A. Ivanova, V.N. Pulyaeva, L.V. Vlasenko, A.A. Gibadullin, M.I. Sadriddinov, Journal of Physics: Conference Series, 1399, 033038 (2019) DOI:10.1088/1742$6596 / 1399 / 3 / 033038$

14. V.V. Davnis, V.I. Tinyakova, V.A. Fetisov, M.A. Chervontseva, S.I. Oparina, International Journal of Recent Technology and Engineering, 8, 3, 254-260 (2019) DOI: $10.35940 /$ ijrte.C1059.1083S19

15. J.V. Gnezdova, E.N. Rudakova, O.P. Zvyagintseva, Studies in Systems, Decision and Control, 169, 211-218 (2019) DOI: 10.1007/978-3-319-94310-7_21

16. I.A. Ivanova, V.N. Pulyaeva, L.V. Vlasenko, A.A. Gibadullin, B.G. Safarov, IOP Conference Series: Earth and Environmental Science, 421, 032039 (2020) DOI: 10.1088/1755-1315/421/3/032039

17. A.A. Gibadullin, M.I. Sadriddinov, Z.M. Kurbonova, Yu.N. Shedko, V.V. Shamraeva, IOP Conference Series: Earth and Environmental Science, 421, 032051 (2020) DOI: $10.1088 / 1755-1315 / 421 / 3 / 032051$

18. P.M. Gureev, V.V. Degtyareva, I.S. Prokhorova, Advances in Intelligent Systems and Computing, 1100, (2020) DOI: https://doi.org/10.1007/978-3-030-39319-9_2

19. D.E. Morkovkin, Sententia. European Journal of Humanities and Social Sciences, 1, 41-47 (2019) DOI: 10.25136/1339-3057.2019.1.26990 